\title{
Abbreviations used for citations in law reports and periodicals
}

$\mathrm{AC}$

Acc Ref

ACLC

ACLR

ACSR

Ad \& El

All ER

All ER (D)

ALR

Am Cur

Am Jo of Compar

Law

Am Jo of Int Law

App Cas

Ariz Law Rev

Aust Insolv Jo

Aust Jo of Corp

Law

Aust Jo of Man

Bailii

Barn Ch

$\mathrm{BCC}$

BCLC

Beav

Bing
Appeal Cases

Accounting Reform

Australian Corporate Law Cases

Australian Corporate Law Reports

Australian Corporate and Securities Reports

Adolphus and Ellis (English Reports)

All England Law Reports

All England Law Reports (Digest)

Australian Law Reports

Amicus Curiae

American Journal of Comparative Law

American Journal of International Law

Appeal Cases

Arizona Law Review

Australian Insolvency Journal

Australian Journal of Corporate Law

Australian Journal of Management

British and Irish Legal Information Institute

Barnardiston's Chancery Reports (English

Reports)

British Company Cases

Butterworths Company Law Cases

Beavan (English Reports)

Bingham (English Reports) 
BJIBFL

Bond Law Rev

BPIR

Camp

Can Bus L Jo

Cap Mark Law Jo

CFILR

Ch

Ch App

CJQ

$\mathrm{Cl} \& \mathrm{~F}$

CLJ

CLP

CLR

CLWR

CMLR

Co Law

Colum L Rev

Conv

Corp Gov

$C$ \& $\mathrm{P}$

CRI

CSIH

C\&SLJ

$\mathrm{CSOH}$

De G, F \& J

DLR

East

EBLR

EBOL Rev

ECFLR

ECHR
Butterworths Journal of International Banking and Financial Law

Bond Law Review

Bankruptcy and Personal Insolvency Reports

Campbell (English Reports)

Canadian Business Law Journal

Capital Markets Law Journal

Company Financial and Insolvency Law Review

Chancery

Chancery Appeals

Civil Justice Quarterly

Clark and Finnelly (English Reports)

Cambridge Law Journal

Current Legal Problems

Commonwealth Law Reports

Common Law World Review

Common Market Law Reports

The Company Lawyer

Columbia Law Review

Conveyancer and Property Lawyer

Corporate Governance: An International Review

Carrington and Payne (English Reports)

Corporate Rescue and Insolvency

Court of Session Inner House (neutral citation)

Corporate and Securities Law Journal

Court of Session Outer House (neutral citation)

De Gex, Fisher and Jones (English Reports)

Dominion Law Reports

East (English Reports)

European Business Law Review

European Business Organisations Law Review

European Corporate and Financial Law Review

European Court of Human Rights (neutral

citation) 
ECR

Edin L Rev

EHRR

$\mathrm{El} \& \mathrm{Bl}$

ELR

Ent Theory and

Pract

ER

EWCA Civ

EWCA Crim

EWHC

Ex

Exch

FCA

Ford Int Law Jo

Griff L Rev

Hare

Harv L Rev

HCA

HL Cas

ICCLR

ICJ Rep

ICLQ

ICR

IECA

IEHC

IESC

IIR

IJLMA

IL \& P

ILRM
European Cases Reports

Edinburgh Law Review

European Human Rights Reports

Ellis and Blackburn (English Reports)

European Law Review

Entrepreneurship Theory and Practice

English Reports

England and Wales Court of Appeal Civil

Division (neutral citation)

England and Wales Court of Appeal Criminal

Division (neutral citation)

England and Wales High Court (neutral citation)

Exchequer Reports (English Reports)

Exchequer Cases

Federal Court of Australia

Fordham International Law Journal

Griffith Law Review

Hare (English Reports)

Harvard Law Review

High Court of Australia (neutral citation)

House of Lords Cases (English Reports)

International Company and Commercial Law

Review

International Court of Justice Reports

International and Comparative Law Quarterly

International Corporate Rescue

Irish Court of Appeal

Irish High Court (neutral citation)

Irish Supreme Court (neutral citation)

International Insolvency Review

International Journal of Law and Management

Insolvency Law and Practice

Irish Law Reports Monthly 
Ins Intell

Ins Law

Int Jo of Disc and Gov

Int Jo of Ent Behav and Res

Int Rev of Law and Econ

IR

Ir Jur

JAL

JBL

JCLS

JLS

Jo of Econ Hist

Jo of Econ

Perspectives

Jo of Euro Econ

Hist

Jo of Fin

Jo of Fin Crime

Jo of Fin Reg and Comp

Jo of L Hist

Jo of Law and Econ

Jo of Law and Soc

Jo of Law Soc Scot

Jo of Pol Econ

KB

Law and Cont Prob

Law and Fin Mark

Rev

Law Teach

Leg Hist

Ld Raym
Insolvency Intelligence

Insolvency Lawyer

International Journal of Disclosure and

Governance

International Journal of Entrepreneurial

Behaviour and Research

International Review of Law and Economics

Irish Reports

Irish Jurist

Journal of African Law

Journal of Business Law

Journal of Corporate Law Studies

Journal of Law and Society

Journal of Economic History

Journal of Economic Perspectives

Journal of European Economic History

Journal of Finance

Journal of Financial Crime

Journal of Financial Regulation and Compliance

Journal of Legal History

Journal of Law and Economics

Journal of Law and Society

Journal of the Law Society of Scotland

Journal of Political Economy

King's Bench

Law and Contemporary Problems

Law and Financial Markets Review

Law Teacher

Legal History

Lord Raymond (English Reports) 
Leg Stud

Lloyds Rep

LMCLQ

LQR

Maas Jo of Euro and

Compar Law

Manag Law

Mass

Melb Jo of Int Law

Melb Univ L Rev

MLR

NI

NICA

NICh

NILQ

NI Master

Nottm Law Jo

NSWCA

NSWLR

NSWSC

NW

NZBLQ

NZLR

OJLS

Ox Univ Comm LJ

PCC

$P \& C R$

$\mathrm{P}$ Wms

QB

RALQ

Recov
Legal Studies

Lloyds Law Reports

Lloyds Maritime and Commercial Law

Quarterly

Law Quarterly Review

Maastricht Journal of European and

Comparative Law

Managerial Law

Massachusetts Reports (USA)

Melbourne Journal of International Law

Melbourne University Law Review

Modern Law Review

Northern Irish Reports

Northern Irish Court of Appeal (neutral citation)

Northern Ireland Chancery Division (neutral citation)

Northern Ireland Legal Quarterly

Northern Ireland Master's Decisions (neutral citation)

Nottingham Law Journal

New South Wales Court of Appeal

New South Wales Law Reports

New South Wales Supreme Court

North Western Reporter (USA)

New Zealand Business Law Quarterly

New Zealand Law Reports

Oxford Journal of Legal Studies

Oxford University Commonwealth Law Journal

Palmer's Company Cases

Property and Compensation Reports

Peere Williams (English Reports)

Queen's Bench

Receivers, Administrators and Liquidators

Quarterly

Recovery 
SALJ

SA Merc L Jo

$\mathrm{SC}$

SCC

SGCA

Sim

Sing Ac LJ

SJ

SLT

SMCLN

Stan L Rev

Stat L Rev

STC

STI

Syd L Rev

The Econ Hist Rev

TLR

TR

UKFTT

UKHL

UKPC

UKSC

UKUT

Univ Chic L Rev

Univ Tasm L Rev

US

Utah L Rev

WASCA

WLR

WN

$\mathrm{Y} \& \mathrm{C}$ Ex

ZASCA
South African Law Journal

South African Mercantile Law Journal

Session Cases

Supreme Court of Canada

Singapore Court of Appeal (neutral citation)

Simons Reports (English Reports)

Singapore Academy of Law Journal

Solicitors' Journal

Scots Law Times

Sweet and Maxwell's Company Law Newsletter

Stanford Law Review

Statute Law Review

Simon's Tax Cases

Simon's Tax Intelligence

Sydney Law Review

The Economic History Review

Times Law Reports

Taxation Reports

UK First Tier Tax Tribunal (neutral citation)

House of Lords (neutral citation)

United Kingdom Privy Council (neutral citation)

United Kingdom Supreme Court (neutral citation)

UK Upper Tribunal (neutral citation)

University of Chicago Law Review

University of Tasmania Law Review

US Supreme Court Reports

Utah Law Review

Western Australia Supreme Court of Appeal

Weekly Law Reports

Weekly Notes

Younge \& Collyer (English Reports)

Supreme Court of South Africa (neutral citation) 